\title{
The Influence of the Dimensions of Service Quality and Customer Satisfaction on Repurchase Intention of Customers of Rocky Plaza Hotel Padang
}

\author{
Dedi Media Agusman', Susi Evanita², Rosyeni Rasyid ${ }^{3}$ \\ ${ }^{1}$ Universitas Negeri Padang, Padang, Indonesia, $\square$ dedimedia@gmail.com \\ ${ }^{2}$ Universitas Negeri Padang, Padang, Indonesia, $\bowtie$ susievanita@gmail.com \\ 3 Universitas Negeri Padang, Padang, Indonesia, $\bowtie$ rosyenirasyid@gmail.com
}

\begin{abstract}
This research aims to analyze the influence of the dimensions of service quality and customer satisfaction on repurchase intention. The population of this study is customers who came to Rocky Plaza Hotel based on the number of rooms sold which amounted to 98 people whit the sampling technique using probabilitysampling. Data collection is done by filling out questionnaires and data analysis techniques used path analysis. The results of the study show that the responsiveness and assurance variables have a significant influence on the interest in repurchasing Rocky Plaza Hotel Padang customer. Whereas for tangible, reliability, empathy and customer satisfaction does not have a significant effect on the interest in repurchasing customers of Rocky Plaza Hotel Padang. The total direct and indirect influence in this study is $20.56 \%$ and the remaining $79.4 \%$ is influence by other variables not explained in this study.

Keywords: tangible, reliability, responsiveness, assurance, empathy, customer satisfaction and repurchase intention
\end{abstract}

\section{Introduction}

Since last few year efforts to develop, tourism has received government attention, especially in areas that have tourist attractions. This situation opens opportunities for the business sector in tourism and hotels to serve domestic and foreign demands. Tourism is also an activity and interaction of humans with their environment. The interaction is done through appreciation, hopes and desires for the environment so that it can give a sense of satisfaction. Competition in the hospitality industry is increasing. Every star hotel or small hotel certainly wants to survive. If the excess room is left alone, it can trigger a tariff war. Tariff war or the decline in room prices in each hotel is actually not good for an industry, because it relates to the employment and fate of hotel employees so that steps to overcome poverty are not achieved. In the tariff war, the selection of rooms is still determined by consumers where consumers will definitely choose the best facilities at low prices so that small hotels have the potential to lose turnover and cannot always survive. If indeed there is finally competition between small and large hotels, then what every hotel can do to survive is to maintain or improve the quality of hotel services and understand market demands.

Hospitality services in Padang have developed quite rapidly, we can see this with the proliferation of hotels competing in this service provider business. Potential big prospects make the hotel services business have a high attractiveness for entrepreneurs to try out the business. However, due to the many players in this business there will be intense competition, to be able to maintain its position and stay in competition the company must understand the characteristics of customers and understand how customers determine their buying interest. So that by understanding customer behavior in the process of his interests, the company will be able to influence these customers later to use their products. According to Friffin in Sopiah and Sangadji (2013: 8), customer behavior is all the process of activities, actions and psychological processes that encourage these actions at the time before buying, when buying, using, spending products and services after doing the things above or activities evaluate. 
In its development, the hospitality industry in the city of Padang has experienced year-on-year growth as evidenced by the large number of new hotels built and can be described in the table below with Rocky competitors' occupancy rates much different from other hotels based on January, February and December 2017 data:

Table 1 Hotel Compatitor Data

\begin{tabular}{lccc}
\hline \multicolumn{1}{c}{ Hotels } & \%Occ Dec & \%Occ Jan & \%Occ Feb \\
\hline Rocky & 79.95 & 47.34 & 42.35 \\
\hline $\begin{array}{l}\text { Pangeran } \\
\text { Beach }\end{array}$ & 77.29 & 40.22 & 46.93 \\
\hline Mercure & 89.11 & 79.45 & 63.01 \\
\hline Axana & 85.29 & 16.91 & 55.15 \\
\hline Bumiminang & 80.49 & 50.6 & 37.5 \\
\hline Grand Inna & 75.02 & 28.57 & 33.93 \\
\hline Premier Basko & 82.83 & 48.33 & 52.22 \\
\hline Grand Zuri & 92.59 & 60.31 & 66.41 \\
\hline Total & 663 & 372 & 398 \\
\hline
\end{tabular}

Source: Data competitor report Rocky Plaza Hotel Padang.

From table 1 above, it can be seen that the level of occupancy of Rocky Plaza Hotel Padang in January and February 2017 has decreased due to less customer buying interest. While in December 2017 occupancy has increased. And this is very interesting for researchers to find out the causes of occupancy instability that occurred at Rocky Plaza Hotel Padang. Thus the purpose of this study is to analyze about:

1. The influence of tangible on service quality on the interest of repurchase(repurchase intention) customersof Rocky Plaza Hotel Padang customers.

2. The influence of reliability on service quality on the interest of repurchase(repurchase intention) customersof Rocky Plaza Hotel Padang customers.

3. The influence of responsiveness on service quality on the interest of repurchase(repurchase intention) customers of Rocky Plaza Hotel Padang customers.

4. The influence of assurance on service quality on the interest of repurchase (repurchase intention) customers of Rocky Plaza Hotel Padang customers.

5. The influence of empathy on service quality on the interest of repurchase(repurchase intention) customers of Rocky Plaza Hotel Padang customers.

6. The influence of customer satisfaction on service quality on interest in repurchase(repurchase intention) Rocky Plaza Hotel Padang customers.

\section{Repurchase Intention}

The definition of interest in repurchasing according to Peter \& Olson is a purchase activity that is carried out more than once or several times. Satisfaction obtained by a customer can encourage someone to make a repeat purchase, be loyal to the product or loyal to the shop where he bought the item so that customers can tell good things to others.

According to Corin et al. the notion of repurchase interest is the behavior of customers where customers respond positively to what has been given by a company and are interested in making a return visit or consuming the company's products again. While according to Fornell said that consumers who are satisfied will make a repeat visit in the future and also tell others about the product or service that they feel.

Some of the factors that influence customer buying interest according to Lidnyawatie (2008) are, Job differences, socio-economic differences, hobby differences, gender differences and age differences. 
The indicators of requesting a repeat purchase are:

1. Transactional interest, namely the tendency of consumers to always buy back products that have been consumed.

2. Referential interest, namely the willingness of consumers to recommend products that have been consumed by others.

3. Preferential interest, namely consumer behavior that makes the product consumed as the first choice.

4. Explorations interest, namely the desire of consumers to always look for information about the products they are interested in.

\section{Customer Satisfaction}

According to Kotler customer satisfaction is the level of one's feelings after comparing (performance or results) that is felt compared to his expectations. Customers can understand one of the three levels of general satisfaction, namely if the performance is below expectations, the customer will feel disappointed, but if the performance is in line with expectations the customer will feel satisfied and if the performance can exceed expectations, the customer will feel very satisfied, happy or happy.

According to Supranto's customer satisfaction is a label used by customers to summarize a set of visible actions or actions related to a product or service. Meanwhile, according to the journal Bachtiar (2011), customer satisfaction is a positive feeling of customers related to products or services while using or after using services or products.

According to Gaspersz (2011) there are several characteristics of services that customers want are the timeliness of service, accuracy of service, politeness and friendliness, responsibility, completeness, ease of service, personal service, comfort and other supporting attributes. Kotler identified four methods for measuring customer satisfaction:system of customer complaints and suggestions, customer satisfaction surveys, shopping ghost and lost customer analysis.

\section{Service Quality}

Service quality is defined as the assessment of customers for superior services or features of a product or service as a whole. According to Lupiyoadi (2013), one of many service quality approaches that has been used as a reference in marketing research is the SERVQUAL (servqual quality) model developed by Parasuraman, Zeithaml, and Berry in a series of research on six service sectors: reparation, household appliances, credit card, insurance, long-distance telephone connections, retails and securities brokers.

SERVQUAL is built on a comparison of two main factors, namely customer perceptions of the actual service received by the expected service. If reality is more than expected, then the service is said to be of good quality whereas if reality is less than expected, the service is said to be of poor quality. And if the reality is the same as expected, the service is called satisfactory. Thus service quality can be defined as how far the difference between reality and customer expectations for the service they receive.

The dimensions of service quality characteristics are:

1. Tangible / direct evidence, is clear evidence of the care and attention given by service providers, especially to customers. The importance of this dimension will grow the image of service providers, especially for new customers in evaluating the quality of services.

2. Reliability, is the company's ability to carry out services in accordance with what has been promised in a timely manner. The importance of this dimension is that customer satisfaction will decrease if the services provided are not as promised. So the component or element of this dimension is the company's ability to deliver services appropriately and charge costs appropriately.

3. Responsiveness, namely the ability of the company to be carried out directly by employees to provide service quickly and responsively. Responsiveness can foster a positive perception of the quality of services provided. Including if there is a failure or delay in the delivery of services, the 
service provider seeks to repair or minimize customer losses immediately. This dimension emphasizes the attention and speed of employees who are involved in responding to customer requests, questions and complaints. If the component or element of this dimension consists of the readiness of employees in serving customers, the speed of employees in serving customers and handling customer complaints.

4. Assurance / guarantee, is the knowledge and behavior of employees to build trust and confidence in consumers in consuming the services offered. This dimension is very important because it involves customer perceptions of the risk of high uncertainty with regard to the ability of service providers. The company builds customer trust and loyalty through employees who are directly involved in handling customers. So the components of this dimension consist of employee competencies which include skills, knowledge possessed by employees to do service and credibility of the company which includes matters relating to customer trust in the company such as, company reputation, achievements and others.

5. Empathy is the ability of the company to be carried out directly by employees to give attention to individual customers, including sensitivity to customer needs. So the component of this dimension is a combination of access, namely the ease of utilizing the services offered, communication which is the ability to convey information to customers and understanding which is an attempt to know and understand the needs and desires of customers.

\section{The influence of Dimensions of Service Quality on repurchase intention}

Several things in the quality dimension are tangible, reliability, responsivenees, assurance and empathy. Customers view service quality as an important part. Therefore companies must strive to provide the best quality in products or services to satisfy the needs and desires of customers, so that customers will later be interested in making repeat purchases in the future. So with the quality of service will be able to influence the interest of repurchasing customers. Because everyone will certainly pay attention to the quality they buy so that these customers will not feel disappointed or hurt.

\section{The influence of Customer Satisfaction on repurchase intention}

Customer satisfaction is a short-term incentive or short-term drive to encourage customers to repurchase. Therefore, customer satisfaction is quite even very important for the company. Customer satisfaction is an encouragement or desire for customers to repurchase, both for prospective new customers or customers who have used the company's products or services before.

The following is an overview of the research conceptual framework in Figure 1:

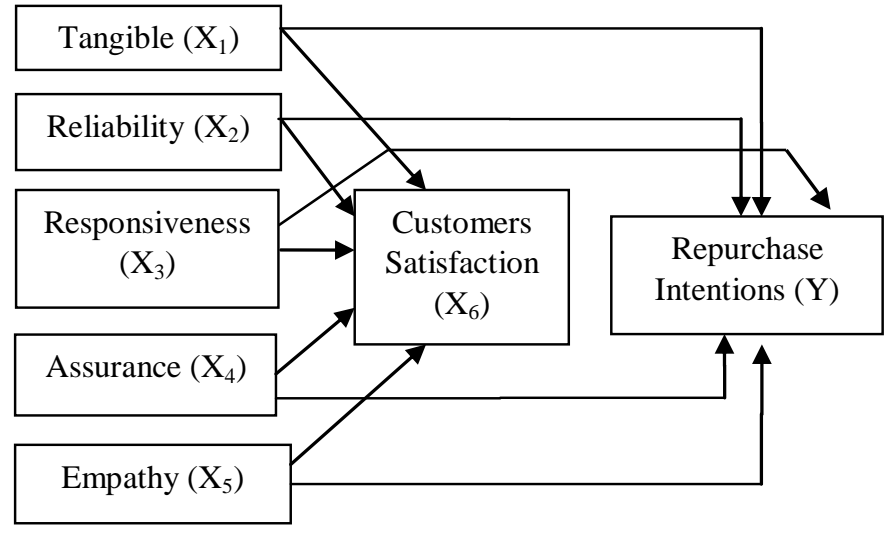

Figure 1 Research Conceptual Framework 


\section{Methods}

The author conducts data collection in this study in the form of information relating to the problem under study. The research method used is descriptive and verification method. The sample from this study amounted to 98 people. Sampling is done by simple random sampling technique.

\section{Result and Discussion}

Based on hypothesis testing, it can be seen the direct and indirect influences of exogenous variables on edogenous variables which are displayed in Figure 2 as follows:

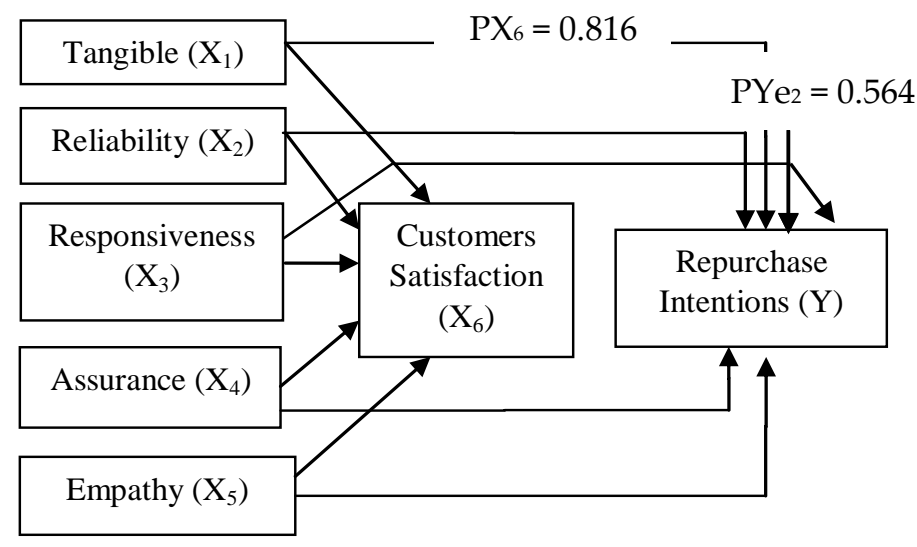

Figure 2 Indirect Influences Of Exogenous Variables on Edogenous Variables

In the following table, it can be seen clearly the direct influence and indirect influence between the causes and variables due to results which are displayed in table 2

Table 2 Direct and Indirect Variable Effects of Cause and Variable Effects

\begin{tabular}{|c|c|c|c|}
\hline Num. & Explanation & $\%$ & $\%$ \\
\hline \multirow[t]{2}{*}{1} & $\begin{array}{l}\text { The amount of indirect influence of tangible (X1) on } \\
\text { repurchase interest }(\mathrm{Y}) \text { through customer satisfaction }(\mathrm{X} 6)\end{array}$ & 1.7 & \\
\hline & The total influence of $\mathrm{X} 1$ on $\mathrm{Y}$ & & 1.7 \\
\hline \multirow[t]{2}{*}{2} & $\begin{array}{l}\text { The amount of the indirect influence of reliability }(\mathrm{X} 2) \text { on } \\
\text { repurchase interest }(\mathrm{Y}) \text { through customer satisfaction }(\mathrm{X} 6)\end{array}$ & 0.7 & \\
\hline & The total influence of $X_{2}$ on $Y$ & & 0.7 \\
\hline 3 & $\begin{array}{l}\text { The amount of the direct influence of responsiveness }(\mathrm{X} 3) \text { on } \\
\text { repurchase interest }(\mathrm{Y}) \text { through customer satisfaction }(\mathrm{X} 6)\end{array}$ & 5.9 & \\
\hline \multirow[t]{2}{*}{4} & $\begin{array}{l}\text { The amount of the indirect influence of responsiveness }(\mathrm{X} 3) \\
\text { on repurchase interest }(\mathrm{Y}) \text { through customer satisfaction }(\mathrm{X} 6)\end{array}$ & 0.5 & \\
\hline & The total influence of $X_{3}$ on $Y$ & & 6.4 \\
\hline 5 & $\begin{array}{l}\text { The amount of direct influence of assurance }(\mathrm{X} 4) \text { on } \\
\text { repurchase interest }(\mathrm{Y}) \text { through customer satisfaction }(\mathrm{X} 6)\end{array}$ & 6.5 & \\
\hline
\end{tabular}


Table Cont...

( The amount of indirect influence of assurance (X4) on 0.8 repurchase interest $(\mathrm{Y})$ through customer satisfaction (X6) The total influence of $\mathrm{X}_{4}$ on $\mathrm{Y}$

: The amount of the indirect influence of empathy (X5) on

3.1 repurchase interest $(\mathrm{Y})$ through customer satisfaction (X6) The total influence of $\mathrm{X}_{5}$ on $\mathrm{Y}$

3.1

\& The amount of the indirect influence of customer satisfaction $(\mathrm{X} 6)$ on repurchase interest $(\mathrm{Y})$ The total influence of $\mathrm{X}_{6}$ on $\mathrm{Y}$ 1.4

The total of all variables 21

The influence of other variables on repurchasing 79 interest of customers at Rocky Plaza Hotel

\section{Total} 100

Table 3 Hypothesis of Service Quality on Customer Satisfaction.

\begin{tabular}{|c|c|c|c|c|c|}
\hline \multirow[t]{2}{*}{ Model } & \multicolumn{2}{|c|}{$\begin{array}{l}\text { Unstandardin } \\
\text { ed } \\
\text { Coeffirients }\end{array}$} & \multirow{2}{*}{$\begin{array}{c}\text { Standaritime } \\
\text { d } \\
\text { Coeffirients } \\
\text { Betr }\end{array}$} & \multirow[t]{2}{*}{$\mathrm{t}$} & \multirow[t]{2}{*}{ Sig. } \\
\hline & B & $\begin{array}{c}\text { Std. } \\
\text { frro } \\
\text { I }\end{array}$ & & & \\
\hline (Coustart) & 3976 & 56 & & 0.71 & 0.48 \\
\hline torgbels & 0053 & 0 & 0.145 & 1225 & 022 \\
\hline reliability & 0.115 & 02 & 0.002 & 0.68 & 0.5 \\
\hline respans ivenees & 0.141 & 0.1 & 0.156 & 1203 & 023 \\
\hline assurnace & 0.15 & 0.1 & 0.272 & 2023 & 005 \\
\hline empaty & 0.113 & 02 & 0.075 & 0664 & 051 \\
\hline
\end{tabular}

From table 3 it can be concluded:

Hypothesis 1

H1: Based on the table it is known that sign tangible $0.224>0.05$, it can be concluded that the hypothesis is accepted which means that the variable tangible does not have a significant influence on customer satisfaction.

Hypothesis 2

$\mathrm{H} 2$ : based on the table it is known that reliability signs are $0.498>0.05$, it can be concluded that the accepted hypothesis means that the reliability variable has no significant influence on customer satisfaction.

Hypothesis 3

H3: based on the table it is known that sign responsiveness is $0.232>0.05$, it can be concluded that the hypothesis is accepted, meaning the responsiveness variable does not have a significant effect on customer satisfaction. 
Hypothesis 4

H4: based on the table it is known that sign assurance $0.046<0.05$, it can be concluded that the hypothesis is rejected means that variable assurance has a significant influence on customer satisfaction.

Hypothesis 5

H5: based on the table it is known to sign empathy $0.508>0.05$, it can be concluded that hypotheses are accepted, meaning empathy does not significantly influence customer satisfaction.

Table 4

Hypothesis of Service Quality and Customer Satisfaction with Customers' Repurchase Interests.Hypothesis of Service Quality and Customer Satisfaction with Customers' Repurchase Interests.

\begin{tabular}{|c|c|c|c|c|c|}
\hline \multicolumn{6}{|c|}{ Coefficients $^{a}$} \\
\hline \multirow[b]{2}{*}{ Model } & \multicolumn{2}{|c|}{$\begin{array}{l}\text { Unstandardized } \\
\text { Coefficients }\end{array}$} & \multirow{2}{*}{$\begin{array}{c}\text { Standardized } \\
\text { Coefficients } \\
\text { Beta }\end{array}$} & \multirow[b]{2}{*}{$\mathrm{t}$} & \multirow[b]{2}{*}{ Sig. } \\
\hline & B & $\begin{array}{c}\text { Std. } \\
\text { Erro } \\
\mathrm{r}\end{array}$ & & & \\
\hline (Constant) & 4.733 & 10 & & 0.472 & 0.64 \\
\hline tangibels & 0.069 & 0.1 & 0.097 & 0.88 & 0.38 \\
\hline reliability & 0.307 & 0.3 & 0.085 & 1.01 & 0.32 \\
\hline 1 responsivenees & 0.421 & 0.2 & 0.242 & 2.003 & 0.05 \\
\hline assurance & 0.271 & 0.1 & 0.254 & 1.997 & 0.05 \\
\hline empaty & 0.119 & 0.3 & 0.041 & 0.39 & 0.7 \\
\hline kepuasan pelanggan & 0.232 & 0.2 & 0.12 & 1.248 & 0.22 \\
\hline
\end{tabular}

From table 4 it can be concluded:

Hypothesis 6

H6: based on the known table tangible sign $0.381>0.05$, it can be concluded that the hypothesis is accepted which means that the variable tangible does not have a significant influence on customer repurchase intention.

Hypothesis 7

H7: based on the table it is known that the reliability sign is $0.315>0.05$, it can be concluded that the accepted hypothesis means that the reliability variable has no significant influence on the customer's repurchase intention.

Hypothesis 8

H8: based on the table, it is known that the sign of responsiveness is $0.048<0.05$, it can be concluded that the hypothesis is rejected, meaning the responsiveness have a significant influence on repurchase intention of customers.

Hypothesis 9

H9: based on the table, it is known that sign assurance $0.049<0.05$, it can be concluded that hypotheses are rejected, meaning variable assurance has a significant influence on repurchase intention of customers. Hypothesis 10 
H10: based on the table it is known that sign empathy is $0.697>0.05$, it can be concluded that the hypothesis is accepted meaning that the variable empathy does not significantly influence the repurchase intention of customers.

Hypothesis 11

H11: based on the table, it is known that sing customer satisfaction is $0.215>0.05$, it can be concluded that the hypothesis is accepted, meaning that customer satisfaction variables have no significant influence on repurchase intention of customers.

\section{Test Requirements Analysis}

Normality test

Normality test is a test of normal data distribution. To find out the form of data distribution we can use graphs of distribution and statistical analysis. The use of distribution charts is the easiest and simplest way. This method is done because the form of normally distributed data that follows the normal distribution pattern will follow the bell shape. Whereas statistical analysis uses analysis of curve and skewness curves with indicators of shocks and tensions. The print out of SPSS for normality tests can be seen in the graph below:

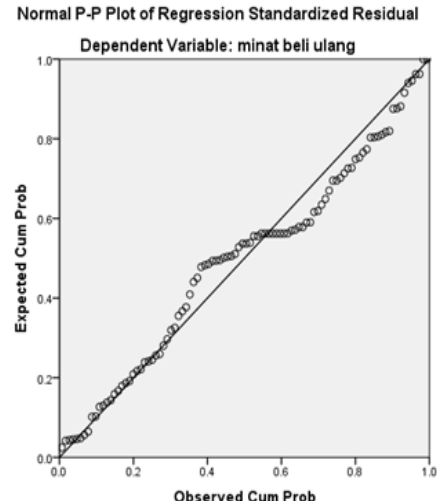

Observed Cum Prob

Histogram

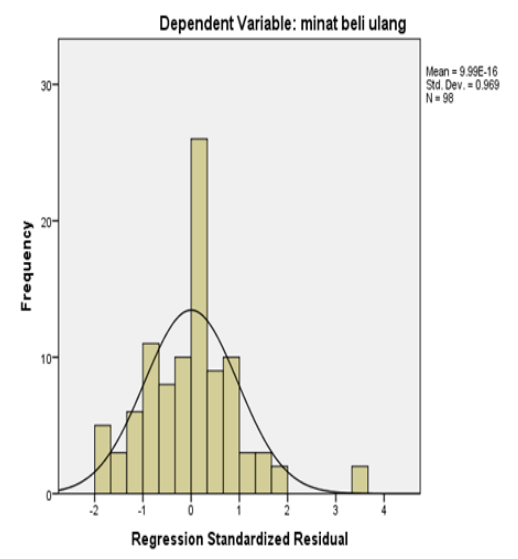

Source: Data Print out SPSS

Figure 3 normality tests

From the output graph we can see a graph of the form of repurchase following a normal distribution with a more histogram equal to the normal distribution. Besides using histograms, we can also see the normality test with the PP Plots chart. A data will be normally distributed if the expected probability is 
the same as the probability value. In the PP Plot graph, it is discussed between probability values and probabilities of valuation with a diagonal line which is the intersection between the probability line and the probability of observation. From the graph it appears as the PP Plot value located around the diagonal line. The PP plot if we look far away the value of the PP Plot does not deviate far from the diagonal line, so that it can be interpreted as data on the re-purchase interest of Rocky Plaza Hotel Padang is normal.

\section{Multicollinearity Test}

Multicollinearity test is a form of testing for assumptions in path analysis. The assumption of multicollinearity states that independent variables must be free from the symptoms of multicollinearity. Symptoms of multicollinearity are symptoms of correlation between independent variables. This symptom is indicated by a significant correlation between the independent variable data.

Table 5 Multicollinearity Test

\begin{tabular}{|c|c|c|}
\hline \multirow{2}{*}{ Model } & \multicolumn{2}{|c|}{$\begin{array}{c}\text { Co lline a rity } \\
\text { Statis tics }\end{array}$} \\
\hline & $\begin{array}{l}\text { Toler } \\
\text { ance }\end{array}$ & VIF \\
\hline (Constant) & & \\
\hline tangibels & 0.511 & 1.96 \\
\hline re liability & 0.873 & 1.15 \\
\hline 1 res pons ivenees & 0.426 & 2.35 \\
\hline assurance & 0.383 & 2.61 \\
\hline empaty & 0.572 & 1.75 \\
\hline $\begin{array}{l}\text { kepuasan } \\
\text { pelanggan }\end{array}$ & 0.666 & 1.5 \\
\hline
\end{tabular}

The multicollinearity test is known from the VIF value for each predictor. If the VIF value is $<10$, it can be concluded that the model is not subject to multicollinearity problems. From table 6 the coefficient is obtained far from a small VIF value of 10 , so that it is free from multicollinearity cases.

\section{Heterocyticity test}

One of the assumptions test in path analysis is heterocediathicity test. The assumption of heterocyticity is the assumption that the residuals are not the same for one observation to another. In path analysis, one that must be fulfilled is that the residual variance from one observation to another does not have a certain pattern. This unequal pattern is indicated by a value that is not equal between one variance of the residual. Symptoms of unequal variance are called symptoms of heterocedasticity. One test to test this heterocedasticity is to look at the spread of residual variance which can be illustrated in the figure below: 


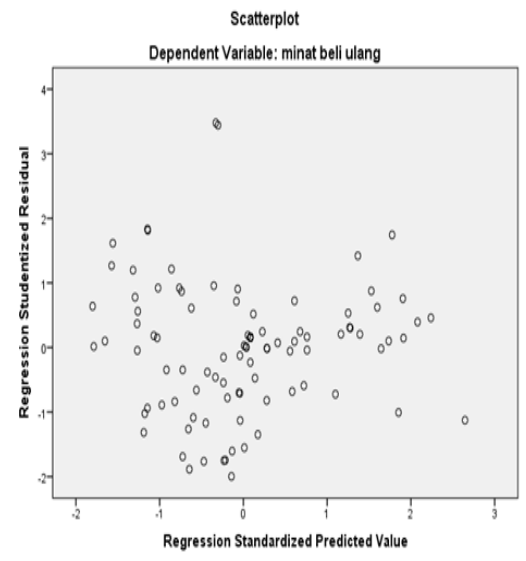

Source: Data Print out SPSS

Figure 4 heterocedasticity Test

From the results of the picture above shows that the spread of residuals is not regular. This can be seen in the plot that radiates and does not form a certain pattern. With these results, the conclusion that can be taken is that there are no homocedasticity symptoms or the regression equation meets the assumption of heterocedasticity.

The influence of tangible (physical evidence) on customers repurchase intentions at Rocky Plaza Hotel Padang

Based on the hypothesis testing, it was found that the tangible did not significantly influence the interest in repurchasing of customers at Rocky Plaza Hotel. From the results of the study it was found that the non-influential tangible at Rocky Plaza Hotel was caused by Customers who come are regular customers, so they don't have a problem with the physical form in the hotel, customers who come from corporate and government who have worked together from the past with Rocky Plaza Hotel and customers already feel close to all employees and staff so they feel like home.

\section{The influence of reliability on customers repurchase intention at Rocky Plaza Hotel Padang}

Based on the hypothesis testing, it was found that reliability did not significantly influence the repurchase intention of customers at Rocky Plaza Hotel. Where this means that the level of employee responsiveness is not too influential on repurchase intention of customers, not affected due to most employees are reliable in handling customers because employees are experienced and often participate in excellent service training from professional trainers, check-in and check-out is done within the normal time limit and a sofa is provided for customers who wait for a long time and every employee outlet is always stand by so that customers are easier for every customer need, such as asking for a spoon, asking for a wifi password, refilling drinking water or ordering other foods.

The theory related to the results of this study is the theory of Lindyawatie (2008), there are several factors that influence customer buying interest, namely, job differences, socio-economic differences, hobby differences, gender differences and age differences.

The results of this study are not in line with the research conducted by Chandra Dewi (2014) entitled "The Influence of Service Quality on Satisfaction and Interest in Buying Consumers in Surakarta Bogabogi Restaurant". The hypothesis results show reliability has a significant effect on the repurchase of Surakarta Boga-bogi Restaurant. 


\section{The influence of responsiveness on repurchase intention Rocky Plaza Hotel Padang customers}

Based on the testing of hypotheses obtained that the responsivenees have a significant influence on repurchase intention of customers at Rocky Plaza Hotel. From the results of the descriptive analysis can be seen in the average level of achievement of respondents to the responsivenees is $76.68 \%$ in the fairly good category. Responsiveness given to customers has a significant influence on the customer's buying interest. Responsiveness in serving customers must be considered in order to solve problems or complaints that occur in the field. Employees must also be responsive to every complaint from customers and be able to solve it well. Good communication between customers and employees must also be maintained and customer language speech must also be responded to and examined carefully so there is no miss communication with customers

The theory related to the results of this study is the theory of Swastha and Irawan (2001) which presents factors that influence repurchase intention related to feelings and emotions, if someone feels happy and is responded well to buying goods or services then it will strengthen interest to buy, his dissatisfaction will eliminate interest.

The results of this study are not in line with the research conducted by NadyaOktaviani entitled "The Effect of Service Quality on Carrefour Bandung Repurchase Interest". The results of the hypothesis indicate that the responsivenees do not have a significant influence on consumers' purchases of Carrefour Bandung.

\section{The influence of assurance on repurchase intention Rocky Plaza Hotel Padang customers}

Based on the testing of hypotheses obtained that the guarantee has a significant influence on repurchase interest. This means that the better the guarantee that the employee has, the higher the interest in repurchasing Rocky Plaza Hotel customers.

From the results of the descriptive analysis, it can be seen that the average level of achievement of respondents to assurance is $75.41 \%$ in the fairly good category. The availability of information is enough to guarantee that the hotel is safe so that it can make customers return to Rocky Plaza Hotel. Hospitality and courtesy of employees are also able to provide assurance that Rocky Plaza Hotel has positive values and good views for customers. With the existence of security guarantees such as the availability of adequate parking and 24 hour security, which is always on standby.

The theory that is related to the results of this study is Gaspersz's theory (2011), the characteristics of services desired by customers, one of which is responsibility (guarantee) relating to receiving orders and handling external customer complaints.

The results of this study are in line with the research conducted by Sri Nikmah (2013) with the title "Analysis of Effect of Price Perception, Product Quality, Service Quality on the Repurchase Interest of Indosat IM3 Prepaid Cards". The results of the research hypothesis indicate that assurance has a significant influence on the interest in Repurchasing Prepaid Cards Indosat IM3.

\section{The influence of empathy (empathy) on repurchase intention Rocky Plaza Hotel Padang customers}

Based on the hypothesis testing it was found that empathy did not significantly influence the repurchase intention of customers at Rocky Plaza Hotel. Where this means that the level of employee empathy is not too influential on repurchase intention caused by employees already understand what customer needs, because generally the customers who come are regular customers and employees serve each customer with attention that makes the customer feel close to the employee so that the customer comes back to visit.

The theory related to this research is the theory of Lindyawatie (2008), there are several factors that influence customer repurchase intention, namely, differences in employment, socio-economic differences, hobby differences, gender differences and age differences. 
The results of this study are not in line with the research conducted by Chandra Dewi (2014) entitled "The Influence of Service Quality on Satisfaction and Interest in Buying Consumers in Surakarta Bogabogi Restaurant". The hypothesis shows that empathy has a significant effect on the repurchase of Surakarta Boga-bogi Restaurant

\section{The Influence of customer satisfaction on repurchase intention of Rocky Hotel's customers}

Based on the testing of hypotheses, it was found that customer satisfaction did not significantly influence the repurchase intention of customers at Rocky Plaza Hotel. Where this means that the level of customer satisfaction is not too influential on the repurchase intention of Rocky Plaza Hotel. Not influential customer satisfaction due to several reasons, including:

1. With the image of the hotel that has been positive and good in the eyes of customers so that customer satisfaction does not really affect the customer's desire to return to visit Rocky.

2. Foods and beverages at Rocky Plaza Hotel are specifically for loyal customers.

3. Customers feel that every complaint received can be resolved quickly and precisely. If the complaints cannot be solved by employees, the general manager of Rocky Plaza Hotel does not hesitate to help the customers to resolve existing problems.

The theory related to the results of this study is the theory of Thamrin and Francis (2012), repurchase intention which is an interest in purchases made on past experiences.

The results of this study are not research conducted by Chandra Dewi (2014) entitled "Service Quality towards Satisfaction of Consumer Buying Interest in Surakarta Boga-bogi Restaurant". The hypothesis results show significant customer satisfaction with the repurchase of Surakarta Boga-bogi Restaurant.

In this study, it is proven that the response and guarantee variables have a significant influence on customer repurchase intention, while tangible, reliability, empathy and customer satisfaction are not significant to repurchase intention of Rocky Plaza Hotel Padang customers.

\section{Conclusion}

Based on the results of the research and discussion described above and referring to several theories and the results of previous studies, with regard to the influence of the dimensions of service quality and customer satisfaction on the customer's repurchase intention, the following conclusions can be taken:

1. Tangible does not have a significant influence on customers' repurchase intention, but tangible can provide customer satisfaction so that customers want to go back to Rocky hotel. So whether the physical form is good or not, does not affect the purchase intention of Rocky Plaza Hotel customers.

2. Reliability does not have a significant influence on the customer's repurchase intention, but reliability can provide satisfaction for Rocky Plaza Hotel customers. So weather good or not the reliability is, does not affect repurchase intention of customers at Rocky Plaza Hotel Padang.

3. Responsiveness has a significant influence on repurchase intention of customers at Rocky Plaza Hotel. Employee responsiveness can increase customer purchase intention directly and can also increase satisfaction for Rocky Plaza Hotel Padang customers.

4. Assurance has a significant influence on repurchase intention of customers at Rocky Plaza Hotel. Guarantees that hotels are safe can increase satisfaction for Rocky Plaza Hotel customers.

5. Empathy does not have a significant influence on repurchase intention, but with empathy can provide satisfaction for hotel customers so that customers want to go back to Rocky Plaza Hotel. So weather good or not the empathy is from employees, does not affect repurchase intention of customers at Rocky Plaza Hotel. 


\section{References}

Abdullah, Thamrin \& Francis Tantri, (2012).Manajemen Pemasaran. PT. Raja Grafindo Persada. Depok.

Bachtiar, A.T.H, 2011. Pengaruh Struktural Modal Terhadap Nilai Perusahan Pada Perusahaan Property EFeal Estate. Yang Terdaftar di BEI tahun 2005-2009 skripsi Fakultas Ekonomi. Universitas Padjajaran Bandung.

Chandra Dewi. (2014). Pengaruh Kualitas Pelayanan Terhadap Kepuasan dan Minat Beli Konsumen di Rumah Makan Boga-bogi Surakarta .STIE-AUB Surakarta.

Danang, Sunyoto. (2013). Metodologi Penelitan Akuntansi. PT. Refika Aditama Anggota IKApi. Bandung.

Dewi Maharani Purbasari \& Dewi Laily Purnama Sari. 2018. Pengaruh Kualitas Pelayanan dan Kepuasan Pelanggan Terhadap Pembelian Ulang. Akademi Perdagangan Catur Insan Cendikia. Cirebon.

Gaspersz, Vincent. (2011). Lean Six Sigma for Manufacturing and Service Industries. Penerbit Vinchristo Publication. Bogor.

Kotler, Philip \& Gary Armstrong. (2012). Prinsip-prinssip Pemasaran. Edisi 13.Jilid 1.Erlangga. Jakarta.

]Lupiyoadi, Rambat. (2013). Manajemen Pemasaran Jasa. Selemba Empat. Jakarta.

Nadya Oktaviani. (2015). Pengaruh Kualitas Pelayanan Terhadap Minat Pembelian Ulang Carrefu Bandung.Universitas Telkom. Bandung.

Oetomo, Rahardian Ali \& RiniNugraheni. (2012). Analisis Pengaruh Keragaman Menu, Persepsi Harg dan Lokasi Terhadap Minat Beli Ulang Konsumen (Studi Pada Restoran Waroeng Taman Singosari).

Sopiah \& Sangadji. (2013). Prilaku Konsumen. Penerbit Andi. Yogyakarta.

Sri Nikmah. (2013). Analisis Pengaruh Persepsi Harga, Kualitas Produk, Kualitas Layanan Terhadap Minat Beli Ulang Kartu Prabayar Indosat IM3 (Studi Kasus Pada Mahasiswa Universitas Diponegoro Semarang).

Susanti.(2014). Analisis Kepuasan Pengunjung Terhadap Kualitas Pelayanan Pemandu di Musiem Konferensi Asia Afrika.Universitas Pendidikan Indonesia. Bandung.

Yamit, Zulian. (2010). Manajemen Kualitas Produk \& Jasa.Ekonesia.Yogyakarta 